UDC 330.101

JEL Classification: C130, L690, G140

http://doi.org/10.21272/mmi.2018.4-11

Aleksy Kwilinski,

Ph.D., The London Academy of Science and Business, England

\title{
MECHANISM OF MODERNIZATION OF INDUSTRIAL SPHERE OF INDUSTRIAL ENTERPRISE IN ACCORDANCE WITH REQUIREMENTS OF THE INFORMATION ECONOMY
}

Abstract. In the paper is established that for the effective development of the industrial enterprise in the conditions of the information economy, should be the modernization of the production sphere of the enterprise. The main aim of the research to find out the optimal mechanism of modernization of industrial sphere in accordance with requirements of the information economy for the industrial enterprise development. To solve this problem, a mechanism for modernization of the industrial sphere of an industrial enterprise has been developed in accordance with the requirements of the information economy, which is based on the use of a model for assessing the effect of measures to modernize the production sector and the model of coordination of projects for modernization of the industrial sphere. This allows automation, robotization and informatization of manufacturing and technological processes of an industrial enterprise on the basis of balancing the criteria of maximizing financial results and competitiveness. It was established that the development of an industrial enterprise in the conditions of the information economy should be based on the modernization of the production sector because it is precisely in this area that the largest gap of industrial enterprises from the leading enterprises is observed. Also, an analysis of research in this direction made it possible to conclude that the problem of modernizing of the industry is not new, but the aspect of the development of an industrial enterprise in the process of its adaptation to the information economy is not sufficiently illuminated. Therefore, there is a need to develop a mechanism for the modernization of the industrial sphere of the industrial enterprise in accordance with the requirements of the information economy, which should contain tools for the development of the enterprise in the context of the modern economy and ensure the formation of projects for the modernization of the production sphere, their mutual coordination and coordination of implementation plans, as well as control of implementation. It is proposed to build a mechanism for modernization of the manufacturing sphere of the industrial enterprise in accordance with the requirements of the information economy on the basis of the use of the model of the evaluation of the effect of measures to modernize the production sphere and the model of coordination of projects for the modernization of the industrial sphere. The model for assessing the effect of measures to modernize the production sector is a tool for determining the impact of measures to modernize the production sector on the competitiveness of the industrial enterprise and its financial results, as well as preparing the grounds for the formation of modernization projects, which are groups of related activities. The model for the reconciliation of industrial production modernization projects provides solutions to such tasks as the estimation of connectivity and compatibility of modernization measures, the definition of the resource costs of modernization measures, the definition of the sequence of modernization measures, the grouping of possible measures in the projects of modernization of the production sector. While discussing further research on complex of models and auxiliary tools are developed, which are the basis of the modernization mechanism of the manufacturing sphere of the industrial enterprise in accordance with the requirements of the information economy, which makes it possible to substantiate and implement the development of the industrial sphere of the industrial enterprise in accordance with the peculiarities of functioning in the conditions of the information economy.

Keywords: mechanism, modernization, manufacturing sphere, industrial enterprise, information economy, impact assessment, project coordination.

Introduction. Due to the constant volatility of the information economy, the issue of modernization of industrial enterprises is constantly relevant. After determining the competitiveness of an industrial enterprise for its development, it is necessary to modernize the production sphere to provide a sufficient level of competitiveness of the industrial enterprise within the industry or market. In the conditions of the information economy, special attention needs to be paid to the development of the managerial sphere of

Cite as: Kwilinski, A. (2018). Mechanism of Modernization of Industrial Sphere of Industrial Enterprise in Accordance with Requirements of the Information Economy. Marketing and Management of Innovations, 4, 116-128. http://doi.org/10.21272/mmi.2018.4-11 
an industrial enterprise, which is the completion of the development of other fields, and the integration of automation, robotization and informatization. The digital economy is expanding in several ways. Global production of information and communications technologies (ICT) goods and services now amount to an estimated $6.5 \%$ of global gross domestic product (GDP). Sales of robots are at the highest level ever, worldwide shipments of three - dimensional printers more than doubled and are expected to reach 6.7 million in 2020 - Figure 1 (UNSTAD, 2017).

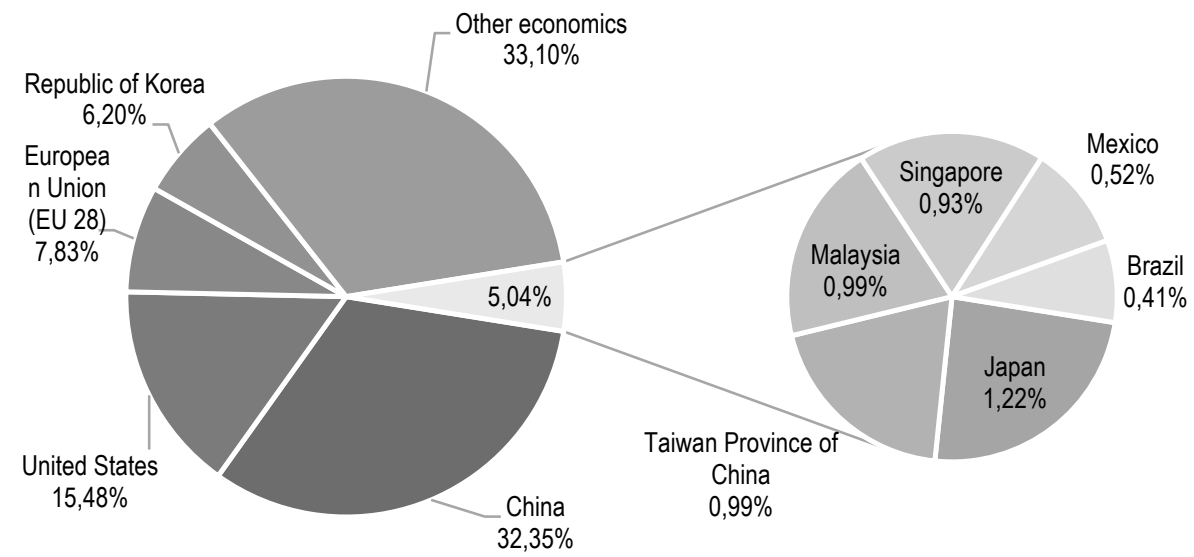

Figure 1 - Manufacturers of the computer, electronic and optical products, 2014 value added, $\$$ billion

Sources: own research on the basis of Eurostat data.

The underlying technologies and processes have far-reaching implications for the organization of work, production and trade, extending existing organizational and geographic fragmentation into knowledge-intensive business functions and job categories or manufacturing firms, digitalization is influencing all segments of the supply chain, from inbound logistics and supplier management to internal processes and customer management. The full impact of the digital economy will only be apparent if and when all these features mature, and become integrated and widely used. However, various factors, such as data security risks, data localization pressures, as well as data collection and privacy concerns, may significantly slow down its development (UNCTAD, 2017). Consequently, it is necessary to take advantage of such perspectives for the development of industry in general and the development of enterprises in particular.

Literature review. The problem of modernization of industry was considered by many researchers (Altenburg, 2011; Cimoli et al., 2009; Graham, 1994; Ivanov et al., 2017; Kharazishvili et al., 2016; Lakhno et al., 2018; Lin, Chang, 2009; Yakubovskiy et al., 2017), but the aspect of the development of an industrial enterprise in the process of its adaptation to the information economy is not sufficiently lit. Among the works in which some elements of this problem were spoken, we should mention the research of $Y$. Benkler (2003; 2006); H. J. Krahn, G. S. Lowe, and K. D. Hughes (2008); G. S. Reddy, R. Srinivasu, S. R. Rikkula, and V. S. Rao (2009); O. O. Plahotnik (2013). 

of the Information Economy

The industrial information economy is the first form of the information economy and has existed since the late- nineteenth century and into the twentieth-century (Benkler 2006). Recently, industrial information economy evolved into a new form known as networked information economy with the advent of the Internet (Benkler 2003).

Adaptation enterprises to the modern economy require the creation of the appropriate infrastructure and propose a strategy for the development of the information infrastructure of the machine-building enterprise (Hroznyi et al., 2018).

The main tool for the development strategy is an information system for automating management decisions (Reddy et al., 2009). The main features of the proposed system are the consideration of external factors in determining the direction of development of economic potential, using of fuzzy modelling and modelling of organizational interaction. The result should be an active, passive or compensatory development model. Among the discussion points of this approach should be noted ignoring the need for modernization of the industrial sphere of enterprises and the need to reconcile this modernization with the general strategy of enterprise development.

The work (Plachotnik, 2013) considers such an option of the information economy as a network economy and offers information support for managing the enterprise's productive potential in a network economy. This information support should be based on the three-level architecture, which includes an information storage system, production capacity management system, decision-making system. But it should be noted that this approach does not consider how to upgrade the production potential in accordance with the requirements of the information economy.

It should also be noted research H. J. Krahn et al. (2008) that studies have considered the peculiarities of the development of industrial enterprises in the conditions of a neo-industrial economy and proposed solutions of some components of this multifaceted problem.

A post-industrial economy refers to a period of growth within an industrialized economy or nation in which the relative importance of manufacturing reduces and that of services, information, and research grows (H. J. Krahn et al., 2008). This is often defined by: (1) A transition to the prevalence of information technologies, which is accompanied by the process of de-industrialization; (2) An introduction of up-todate high-tech production facilities oriented at the output with high share of added value; (3) An informatization of society and development of modern science-intensive service sphere. (Yakubovskiy et al., 2017). But it is worth noting that the most of scientists who studied the issues of modernization of the industrial sphere of the industrial enterprise in accordance with the requirements of the information economy, ignored such tasks as the need to develop a formalized quantitative approach to justifying the directions of modernization in accordance with the problems of functioning in the conditions of information available to the enterprise under the study of economy. Also, insufficient attention is paid to the coordination of the modernization of the industrial sphere of the industrial enterprise with its general development goals.

Therefore, there is a need to develop a mechanism for the modernization of the industrial sphere of the industrial enterprise in accordance with the requirements of the information economy, which should contain tools for the development of the enterprise in the context of the modern economy and ensure the formation of projects for the modernization of the production sphere, their mutual coordination and coordination of implementation plans and control of its implementation.

Methods. Mechanism of modernization of the production sphere. The proposed mechanism of modernization of the industrial sphere of an industrial enterprise in accordance with the requirements of the information economy takes into account the results of the use of the previously described mechanism for assessing the competitiveness of an industrial enterprise in the information economy. The obtained estimates of the competitiveness of an industrial enterprise are the basis for developing measures for its development. The mechanism of modernization of the industrial sphere of an industrial enterprise in 
A. Kwilinski. Mechanism of Modernization of Industrial Sphere of Industrial Enterprise in Accordance with Requirements of the Information Economy

accordance with the requirements of the information economy is based on the use of the model of the evaluation of the effect of measures to modernize the production sphere and the model of coordination of projects for the modernization of the production sector, as shown in Figure 2.

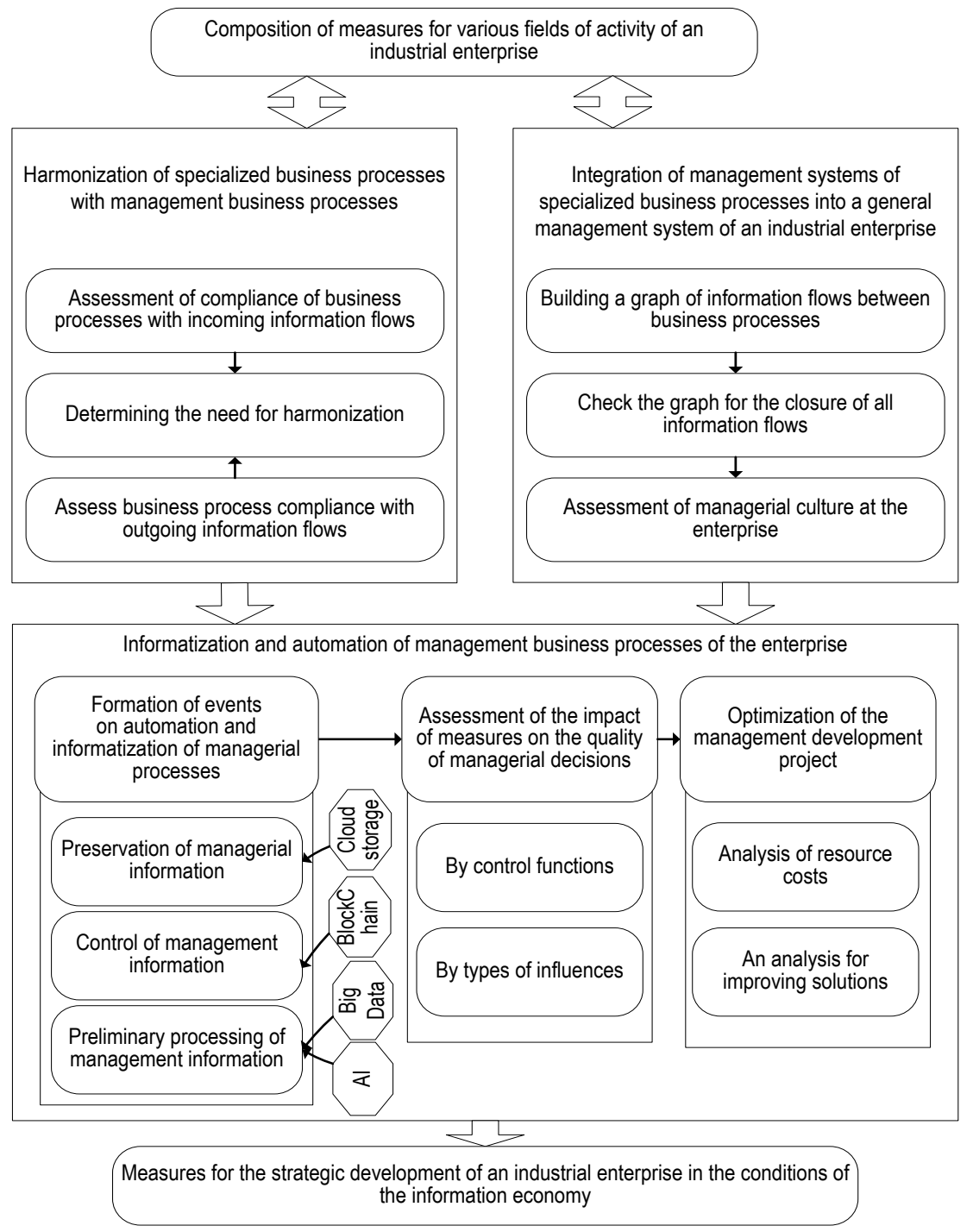

\section{Figure 2 - Mechanism of modernization of the industrial sphere of the industrial enterprise in accordance with the requirements of the information economy}

Sources: own research.

The model for assessing the effect of measures to modernize the production sector is a tool for determining the impact of measures to modernize the production sector on the competitiveness of the industrial enterprise and its financial results, as well as preparing the grounds for the formation of 
modernization projects, which are groups of related activities. The necessity of evaluating competitiveness and financial results is due to the essence of enterprise development in the conditions of the information economy.

On the one hand, an industrial enterprise should be profitable for its owners, that is, to have a profit growth or increase in value. At the same time, it is necessary to ensure the development, that is, the improvement of the state and trajectory of the industrial enterprise in the external environment, which is proposed to evaluate its competitiveness.

Model of evaluation of the effect of measures to modernize the production sector. Modernization of the industrial sphere of an industrial enterprise in the aspect of adaptation to the information economy can be separated by the following general measures:

- robotization of production and technological operations;

- automation of control of production and technological operations;

- use of more efficient equipment;

- improvement of production operations;

- automation of planning and provision of production tasks.

When robotizing manufacturing and technological operations, full automation of work is carried out. Robotic Process Automation (RPA) is an emerging form of business process automation technology based on the notion of software robots or Artificial Intelligence (Al) workers (Hal Hodson, 2015). The most suitable robotizing processes are those that are associated with moving, sorting, welding, spraying, painting products. This is reflected in the cost and quality of products, since it excludes the human factor, increases the safety of production, provides the possibility of continuous work.

Automation of control of production and technological operations gives the opportunity to control the stage at which the product is produced, to respond in a timely manner to the needs for procurement of resources, to detect deviations from plans at the time of their occurrence. Due to the automation of control, the reputation of the company increases, because it allows executing orders exactly in time. One of the main consequences of automation of control is the ability to calculate the cost of each type of product or operation, that is, the introduction of process-oriented management. The use of more efficient equipment means replacing obsolete equipment with a more modern, better energy efficiency (Karpenko et al., 2018), lower percentage of defects, higher productivity, better ergonomics, the ability to integrate into automated systems of enterprise management and the provision of necessary sensors. Such modernization has a direct impact on the financial efficiency of an industrial enterprise (Pajak, 2016; Kwilinski, 2017).

Improvement of production operations relates mostly not to equipment, but directly to the actions of workers and algorithms for the processing of raw materials. Through the use of the latest methods of data collection and processing, the normal production operations can be rethought in a new way, their weaknesses identified, and more advanced algorithms developed.

Automating scheduling and providing manufacturing tasks makes it possible to reduce management chains. This leads to a reduction in the number of errors and distortions of information when moving from lower links to management and in the opposite direction. It also affects the quality of automated production control. From the listed types of events, a number of possible measures for the modernization of the production sector are formed. Proposals for measures are proposed to be received from two sources. The first source is directly the workers and managers of production, who describe the problems that arise in them during the process of production activities and possible directions for their solution. The second source is specialized divisions, such as design bureaus, research departments, IT departments, etc. These subdivisions carry out proposals for modernization measures as a result of the research of technologies already existing in the world from leading enterprises or specialized companies on automation and robotics and substantiate their possibility to use at enterprises.

For each of the proposed measures, estimates are made which are necessary for the further 
development of project evaluations: assessment of the impact of modernization measures on the financial results of an industrial enterprise; assessment of the impact of modernization measures on competitiveness. Calculation of assessments of the impact of modernization measures on the financial results of an industrial enterprise is carried out through evaluation, as each of the measures affects the company's income and expenditures. As a result, the impact on the company's profit can be estimated. For each modernization measure, it is proposed to calculate the average results in the strategic planning range in a few years. This will allow taking into account both the cost of implementing measures and their effect. The most suitable for such an assessment is the net present value:

$$
N P V^{z}=\sum_{t}\left(\frac{V_{t}^{z, \Delta+}-V_{t}^{z, \Delta-}}{(1+r)^{t}}\right)-V^{z}
$$

where $N P V^{z}$ - net present value z-th measure of modernization of production; $V_{t}^{z, \Delta+}$ - an increase in gross revenues of an industrial enterprise owing to the implementation of the $z$-th measure on the modernization of production; $V_{t}^{z, \Delta-}$ - increase of gross expenses of the industrial enterprise as a result of implementation of z-th measures to modernize production; $V^{z}$ - expenses for the modernization of the industrial sphere of the industrial enterprise.

For each of the following components of net present value, there are particular impacts of modernization measures. Typical impacts of measures to modernize the production sector on the financial results of an industrial enterprise are shown in Table 1.

Table 1 - Typical impacts of measures to modernize the production sector to the financial results of the industrial enterprise

\begin{tabular}{|c|c|c|c|}
\hline \multirow{2}{*}{$\begin{array}{c}\text { The direction of } \\
\text { modernization of the } \\
\text { production sphere }\end{array}$} & \multicolumn{3}{|c|}{ Consequences of modernization } \\
\hline & Constant income & Constant costs & $\begin{array}{l}\text { Development and } \\
\text { implementation costs }\end{array}$ \\
\hline $\begin{array}{l}\text { Robotics of production and } \\
\text { technological operations }\end{array}$ & $\begin{array}{l}\text { Increased sales through } \\
\text { improved quality and production } \\
\text { volumes }\end{array}$ & Reduced labour costs & $\begin{array}{l}\text { Purchase of production } \\
\text { equipment, hire of the } \\
\text { necessary personnel }\end{array}$ \\
\hline $\begin{array}{c}\text { Automation of control of } \\
\text { production and technological } \\
\text { operations }\end{array}$ & $\begin{array}{l}\text { Increased product sales through } \\
\text { improved quality }\end{array}$ & $\begin{array}{c}\text { Less percentage of the } \\
\text { defect and accidents }\end{array}$ & $\begin{array}{c}\text { Purchase of production } \\
\text { equipment, training of } \\
\text { personnel }\end{array}$ \\
\hline $\begin{array}{l}\text { Using more efficient } \\
\text { equipment }\end{array}$ & $\begin{array}{l}\text { Increase in product sales due to } \\
\text { increased volumes of production } \\
\text { over the same period of time }\end{array}$ & \begin{tabular}{|l|} 
Reducing energy and \\
materials costs, \\
reducing labour costs
\end{tabular} & $\begin{array}{c}\text { Purchase of production } \\
\text { equipment, training of } \\
\text { personnel }\end{array}$ \\
\hline $\begin{array}{l}\text { Improvement of production } \\
\text { operations }\end{array}$ & $\begin{array}{l}\text { Increase in product sales due to } \\
\text { increased volumes of production } \\
\text { over the same period of time }\end{array}$ & Reducing labour costs & Staff retraining \\
\hline $\begin{array}{l}\text { Automation of planning and } \\
\text { provision of production tasks }\end{array}$ & Accelerating plans & $\begin{array}{c}\text { Reduce the cost of } \\
\text { defects }\end{array}$ & $\begin{array}{l}\text { Staff training, software } \\
\text { purchasing }\end{array}$ \\
\hline
\end{tabular}

\section{Sources: own research}

The next component of the model for assessing the effect of measures to modernize the production sector is the calculation of the impact assessment of the modernization measures on the competitiveness of the industrial enterprise. If in general the development of an industrial enterprise affects all four proposed areas of competitiveness (the degree of automation of production, the degree of representation of the 

of the Information Economy

enterprise in the information space, the degree of informatization of business processes, an absolute assessment of the ability to implement new technologies), then the modernization of the manufacturing sector is mainly associated with automation of production and, in part, with the informatization of business processes. Therefore, it is necessary to have an integrated indicator, which reflects the impact of the measure on the modernization of the manufacturing sector on these components of the overall competitiveness of the enterprise in the conditions of the information economy.

Due to the fact that the calculation of automation and information indicators taking into account each process and its contribution to production is labour-intensive and complex, it is proposed, in the preliminary assessment of the impact of modernization measures, to evaluate only the coverage of each of the measures. Thus, the integrated index can be calculated by the formula:

$$
C M P^{z}=\sum_{i}\left(c_{i}^{z} \times k_{i}^{z}\right)
$$

where $C M P^{z}$ - an integrated indicator that reflects the impact of the z-th measure on the modernization of the manufacturing sector on the components of the overall competitiveness of the enterprise in the conditions of the information economy; $c_{i}^{z}$ - a degree of coverage of production by z-th event (from 0 to 1 , where 1 - this is the coverage of all production processes); $k_{i}^{z}$ - coefficients of the relationship between type z-th event and components of the overall competitiveness of the enterprise in terms of information economy.

The coefficients of the relationship between the types of measures and the components of the company's competitiveness in the conditions of the information economy are determined by the results of the survey of typical projects for the modernization of industrial enterprises, first of all, machine-building enterprises. The proposed coefficients for calculation are shown in Table 2.

Table 2 - Coefficients of connection between types of measures and components of enterprise competitiveness in the conditions of the information economy

\begin{tabular}{|c|c|c|c|c|c|}
\hline \multirow[b]{2}{*}{ Indexes } & \multicolumn{5}{|c|}{ Type of measure for modernization } \\
\hline & 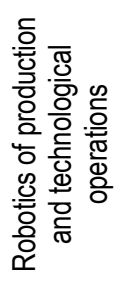 & 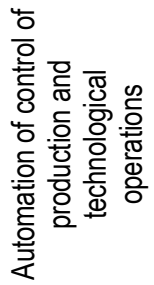 & 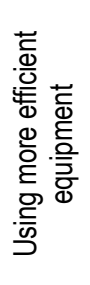 & 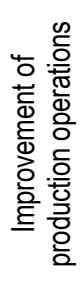 & 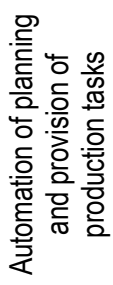 \\
\hline Receipt of production tasks & 0,1 & 0,0 & 0,0 & 0,1 & 0,3 \\
\hline Performance of production tasks & 0,2 & 0,0 & 0,3 & 0,2 & 0,0 \\
\hline Control over the performance of production tasks & 0,1 & 0,3 & 0,0 & 0,0 & 0,3 \\
\hline Availability of a formal description of the business process & 0,1 & 0,05 & 0,2 & 0,2 & 0,1 \\
\hline $\begin{array}{l}\text { Presence of accompanying electronic document flow of the } \\
\text { business process }\end{array}$ & 0,1 & 0,05 & 0,1 & 0,1 & 0,05 \\
\hline Displays the state of the business process execution & 0,2 & 0,3 & 0,1 & 0,1 & 0,1 \\
\hline $\begin{array}{l}\text { Reflection of responsible for the execution of the business } \\
\text { process }\end{array}$ & 0,0 & 0,1 & 0,2 & 0,2 & 0,05 \\
\hline $\begin{array}{l}\text { The presence of an automated system of alerts on deviations } \\
\text { from the schedule of execution of business processes }\end{array}$ & 0,2 & 0,2 & 0,1 & 0,1 & 0,1 \\
\hline
\end{tabular}

Sources: own research 

of the Information Economy

Thus, the result of the evaluation of the effect of measures to modernize the production sector is a pair of values for each of the possible measures. Depending on the primary objectives of the company owners, the importance of each component of this pair of estimates may vary. If an industrial company does not have significant financial reserves or there is a possibility of a close crisis, then the impact of the financial result is more important. If the owners of the industrial enterprise are interested in long-term strategic development in the conditions of the information economy, then the more important is the indicator of the impact of measures to modernize the production sector on the competitiveness of the enterprise.

Models of coordination of projects of modernization of the production sphere. The second model, which underlies the mechanism of modernization of the industrial sphere of an industrial enterprise in accordance with the requirements of the information economy, is the model of coordination of projects for the modernization of the production sphere. This model provides a solution to the tasks:

- calculation of connectivity and compatibility assessments for modernization measures;

- definition of the resource costs of modernization measures;

- determine the sequence of modernization measures;

- grouping of possible measures in the projects of modernization of the production sphere.

To calculate the compatibility of modernization measures, it is necessary to create a working group of specialists for the modernization of the production sphere, which should include both representatives of production units and specialises in the field of information technology and automation of production. They can adequately assess how possible modernization measures affect each other.

When evaluating compatibility, events may be related, compatible or incompatible. If the events are connected, the implementation of the second also requires the implementation of the first.

At the same time, this property in the general case is not inverse, that is, the first can be realized without the second. Incompatibility means that it is advisable to choose only one of the possible measures. If measures are independent, then they can be implemented or not implemented in any order and do not affect each other. All possible measures should be described in a matrix of size $\mathrm{N}^{*} \mathrm{~N}$ (where $\mathrm{N}$ - is the total number of possible measures) in which the relationship between each pair of measures is given. For formalized evaluations, it is suggested to use a system of criteria, which are shown in Table 3.

Table 3 - Criteria for assessing the relevance and compatibility of modernization measures

\begin{tabular}{|c|l|l|}
\hline The type of relation & Variants of formalized evaluation & \multicolumn{1}{|c|}{ Description of evaluation criteria } \\
\hline \multirow{5}{*}{ Connectivity } & Depend on symmetry & They must be carried out simultaneously \\
\cline { 2 - 3 } & Depending on the sequence & Can be implemented in any order \\
\cline { 2 - 3 } & Depends consistently & Should be carried out after another action \\
\cline { 2 - 3 } & Independent & $\begin{array}{l}\text { Execution of one modernization measure } \\
\text { does not affect the other }\end{array}$ \\
\hline \multirow{5}{*}{ Compatibility } & Alternative & Only one of these events can be selected \\
\cline { 2 - 3 } & Desired & $\begin{array}{l}\text { It is desirable, but not necessarily, for both } \\
\text { measures }\end{array}$ \\
\cline { 2 - 3 } & Free & $\begin{array}{l}\text { Execution of one modernization measure } \\
\text { does not affect the other }\end{array}$ \\
\hline
\end{tabular}

Sources: own research

Simultaneously with the estimation of connectivity and compatibility assessments of modernization measures, the resource cost of modernization measures is determined. It is suggested not to distinguish between different types of resources (personnel, material, etc.), but to convert all resources to the monetary value. It is believed that all necessary resources can be purchased by an industrial enterprise in a free economy. Thus, in the model of coordination of projects for the modernization of the production 
sphere, only financial resources are considered.

The grouping of possible measures in the projects of modernization of the production sphere is carried out by constructing a multi-criteria optimization model and studying its sensitivity, as well as analysis of behaviour when changing the criteria of optimization.

As criteria of optimization can be used:

- maximizing the financial result;

- maximizing the competitiveness of the information economy;

- minimizing the amount needed to achieve the set target of resources (as a goal, there may be a financial result or improvement of competitiveness).

That is, in the model of the grouping of possible measures in the projects of modernization of the industrial sphere one or two target functions from three can be used:

$$
\begin{gathered}
\sum_{z}\left(b^{z} * N P V^{z}\right) \rightarrow \max \\
\sum_{z}\left(b^{z} * C M P^{z}\right) \rightarrow \max \\
\sum_{\mathrm{z}}\left(b^{z} * R^{z}\right) \rightarrow \min
\end{gathered}
$$

where $N P V^{z}$ - net present value of the z-th measure for the modernization of production; $C M P^{z}-$ an integrated indicator that reflects the impact of the z-th measure on the modernization of the manufacturing sector on the components of the overall competitiveness of the enterprise in the conditions of the information economy; $R^{z}$ - costs of resources for the implementation of $z$-th measures to modernize the production sector; $b^{z}=0$ or $1-$ a logical variable that reflects whether the z-th measure on modernization of the industrial sphere of an industrial enterprise is involved in the project.

Depending on the selected target functions, one or two of the constraints are used in the model:

$$
\begin{gathered}
\sum_{z}\left(b^{z} * N P V^{z}\right) \geq G^{N P V} \\
\sum_{z}\left(b^{z} * C M P^{z}\right) \geq G^{C M P} \\
\sum_{z}\left(b^{z} * R^{z}\right) \leq G^{R}
\end{gathered}
$$

where $G^{N P V}$ - minimal change in the financial result, which suits the owners of the industrial enterprise; $G^{C M P}$ - minimal change of competitiveness, which suits the owners of industrial enterprises; $G^{R}$ - restrictions on the resources that an industrial enterprise can spend on the modernization of the manufacturing sector; $b^{z}=0$ or $1-$ a logical variable that reflects whether the z-th measure on modernization of the industrial sphere of an industrial enterprise is involved in the project.

The selection of target functions and constraints for constructing modernization projects is carried out in accordance with Table 4. In the general case, the search for a solution is made for all three options for a set of target functions. This enables the management and owners of the industrial enterprise to analyze the effects of different development strategies in the information economy. In addition, for the analysis, variants of modernization can be calculated for different values of constraints $\left(G^{N P V}, G^{C M P}, G^{R}\right)$, thus, a plurality of modernization projects are formed, which are further analyzed in terms of their agreement with the general strategy of development of the industrial enterprise in the conditions of the information economy. 

of the Information Economy

Table 4 - Selection of target functions and constraints in the formation of projects of modernization of the industrial sphere of an industrial enterprise in the conditions of the information economy

\begin{tabular}{|l|l|}
\hline \multicolumn{1}{|c|}{ Target functions } & \multicolumn{1}{|c|}{ Variable restrictions } \\
\hline Maximizing the financial result & $\begin{array}{l}\text { By volume of resources and improvement of } \\
\text { competitiveness }\end{array}$ \\
\hline $\begin{array}{l}\text { Maximizing the competitiveness Improvement in the } \\
\text { Information Economy }\end{array}$ & By volume of resources and financial result \\
\hline $\begin{array}{l}\text { Minimizing the volume needed to achieve the established } \\
\text { goal of resources }\end{array}$ & $\begin{array}{l}\text { By financial result and/or improvement of } \\
\text { competitiveness }\end{array}$ \\
\hline $\begin{array}{l}\text { Maximizing the financial result and maximizing the } \\
\text { competitiveness of the information economy }\end{array}$ & By resources \\
\hline $\begin{array}{l}\text { Maximizing the financial result and minimizing the amount } \\
\text { needed to achieve the set goal of resources }\end{array}$ & For improving competitiveness \\
\hline $\begin{array}{l}\text { Maximizing competitiveness improvement and minimizing } \\
\text { the amount needed to achieve the established purpose of } \\
\text { resource }\end{array}$ & By financial result \\
\hline
\end{tabular}

\section{Sources: own research}

In addition to the changing constraints to the model of the grouping of possible measures in the projects of modernization of the manufacturing sector, there are still constraints that reflect the compatibility of the measures:

$$
\sum_{a \in A}\left(b^{a}\right) \leq 1
$$

where $b^{a}$ - a logical variable that reflects whether the a-th measure for the modernization of the industrial sphere of an industrial enterprise is involved in the project; $A-$ a set of measures that have an alternative compatibility among themselves, that is, of which only one or one of them may be included in the project.

After grouping activities into projects based on previously established connectivity measures for the modernization of the manufacturing sector, it is possible to determine the sequence of measures. For this purpose, it is proposed to use dynamic models of network graphs.

At the same time, each measure is the vertex, and the connection between the measures - the arc. Each arc is relevant to the resources needed to move from one event to another. The calculation of the sequence is a trivial task and can be accomplished using the algorithms of the minimally binding tree or tree branch.

Thus, the proposed set of models and auxiliary tools constitute the mechanism of modernization of the industrial sphere of the industrial enterprise in accordance with the requirements of the information economy, which enables to justify and implement the adaptation of the industrial sphere of the industrial enterprise to the peculiarities of functioning in the conditions of the information economy.

Results. Approbation of the developed mechanism of modernization of the industrial sphere of the industrial enterprise in accordance with the requirements of the information economy was carried out at Enterprise A. Among the measures to modernize the production sector, those that provide a balance between improving the financial result and raising the level of competitiveness in the information economy are selected. Selected measures are shown in Table 5. 
A. Kwilinski. Mechanism of Modernization of Industrial Sphere of Industrial Enterprise in Accordance with Requirements of the Information Economy

Table 5 - Measures to modernize the production sphere of Enterprise A in the conditions of the information economy

\begin{tabular}{|c|c|}
\hline $\begin{array}{l}\text { The direction of modernization of the } \\
\text { production sphere }\end{array}$ & $\begin{array}{l}\text { An event on the modernization } \\
\text { of the production sphere }\end{array}$ \\
\hline $\begin{array}{l}\text { Automation of control of production and } \\
\text { technological operations }\end{array}$ & Automation of entrance control of shaped metal rolling \\
\hline Robotics of production and technological operations & Rotation of the paint camera \\
\hline $\begin{array}{l}\text { Automation of control of production and } \\
\text { technological operations }\end{array}$ & Automation of drying camera control system \\
\hline \multirow{4}{*}{$\begin{array}{l}\text { Automation of planning and provision of } \\
\text { production tasks }\end{array}$} & $\begin{array}{l}\text { Implementation of the use of the lower-level } \\
\text { management at industrial sites of industrial tablets }\end{array}$ \\
\hline & $\begin{array}{l}\text { Development of control system for performance of } \\
\text { production tasks }\end{array}$ \\
\hline & $\begin{array}{l}\text { Training of management of the lower level in the } \\
\text { production areas of the basics of information technology } \\
\text { and work with the interface of industrial tablets }\end{array}$ \\
\hline & $\begin{array}{l}\text { Development of a technical task for the control system } \\
\text { of production tasks }\end{array}$ \\
\hline
\end{tabular}

\section{Sources: own research}

Half of the selected modernization measures are point-and-point and are not related to each other. These are robotic and automation measures for individual equipment or sites that do not require decomposition for several activities. But other measures that relate to the automation of planning and the provision of production tasks need to be subordinated. Thus, in the first stage, the "Development of a technical task for the control system of production tasks" is carried out. After that, in parallel, "Development of a system for controlling the fulfilment of production tasks" and "Training of management of the lower level in the production areas of the basics of information technologies and work with the interface of industrial plates" can be performed in parallel. The final stage is "Implementation of the use of the lower level management by the industrial sites of industrial tablets". The results of the introduction of such a system will be the presence in the global information system of the Enterprise A information on the implementation of the production plan. At the first phase of the modernization of the production sphere, automation of planning and the provision of production tasks is carried out only for the area of mechanical processing, heat treatment areas and procurement area.

As a result of the project on modernization of the manufacturing sector, the cost of production is expected to decrease by $5-12 \%$ (depending on the type of product in the order of the coming years) and the competitiveness increase among competitors in the country by $24 \%$ and among the best competitors in the world by $7 \%$.

Thus, the use of the developed mechanism for modernizing the industrial sphere of an industrial enterprise in accordance with the requirements of the information economy at Enterprise $A$ is relevant and effective.

Conclusions. It was established that the development of an industrial enterprise in the conditions of the information economy should be based on the modernization of the production sector because it is precisely in this area that the largest gap of industrial enterprises from the leading enterprises is observed. Also, an analysis of research in this direction made it possible to conclude that the problem of modernizing of the industry is not new, but the aspect of the development of an industrial enterprise in the process of its adaptation to the information economy is not sufficiently illuminated. Therefore, there is a need to develop a mechanism for the modernization of the industrial sphere of the industrial enterprise in 
accordance with the requirements of the information economy, which should contain tools for the development of the enterprise in the context of the modern economy and ensure the formation of projects for the modernization of the production sphere, their mutual coordination and coordination of implementation plans, as well as control of implementation.

It is proposed to build a mechanism for modernization of the industrial sphere of the industrial enterprise in accordance with the requirements of the information economy on the basis of the use of the model of the evaluation of the effect of measures to modernize the production sphere and the model of coordination of projects for the modernization of the industrial sphere. The model for assessing the effect of measures to modernize the production sector is a tool for determining the impact of measures to modernize the production sector on the competitiveness of the industrial enterprise and its financial results, as well as preparing the grounds for the formation of modernization projects, which are groups of related activities. The model for the reconciliation of industrial production modernization projects provides solutions to such tasks as the estimation of connectivity and compatibility of modernization measures, the definition of the resource costs of modernization measures, the definition of the sequence of modernization measures, the grouping of possible measures in the projects of modernization of the production sector.

A complex of models and auxiliary tools are developed, which are the basis of the modernization mechanism of the industrial sphere of the industrial enterprise in accordance with the requirements of the information economy, which makes it possible to substantiate and implement the development of the industrial sphere of the industrial enterprise in accordance with the peculiarities of functioning in the conditions of the information economy.

\section{References}

Altenburg, T. (2011). Industrial policy in developing countries: overview and lessons from seven country cases. Bonn: German Development Institute. ISBN 978-3-88985-533-6. Retrieved from http://edoc.vifapol.de/opus/volltexte/2011/3341/pdf/DP_4.2011.pdf Benkler, Y. (2003). Freedom in the commons: towards a political economy of information. Duke Law Journal, 52(6), 1245-1276. Benkler, Y. (2006). The wealth of networks: How social production transforms markets and freedom. New Haven and London: Yale University Press.

Cimoli, M., Dosi, G., \& Stiglitz, J. E. (Eds.). (2009). Industrial policy and development. The political economy of capabilities accumulation. Oxford: Oxford University Press.

Graham, O. L. (1994). Losing time: The industrial policy debate. Cambridge, MA: Harvard University Press.

Hodson, H. (2015). Al interns: Software already taking jobs from humans. New Scientist. Retrieved from https://www.newscientist.com/article/mg22630151.700-ai-interns-software-already-taking-jobs-from-humans/\#.VY2CxPIViko

Hroznyi, I., Kuzmak, O., Kuzmak, O. \& Rusinova O. (2018). Modeling management of diversification of foreign economic interactions. Problems and Perspectives in Management. Vol. 16, Vol. 1, 155-165. Retrieved from http://dx.doi.org/10.21511/ppm.16(1).2018.15 df

Information economy report (2017). UNSTAD. Retrieved from http://unctad.org/en/PublicationsLibrary/ier2017_overview_en.p

Ivanov, S., Liashenko, V., Kamińska, B., \& Kvilinskyi, O. (2017). Koncepcja oceny modernizacji [A concept of modernization evaluation]. European Cooperation, 12(19), 86-101.

Karpenko, L., Serbov, M., Kwilinski, A., Makedon, V., Drobyazko, S. (2018). Methodological platform of the control mechanism with the energy saving technologies. Academy of Strategic Management Journal, 175), 1939-6104-17-5-271: 1-7. https://www.abacademies.org/articles/Methodological-platform-of-the-control-mechanism-1939-6104-17-5-271.pdf

Kharazishvili, Y., Lyashenko, V., Zaloznova, Y., \& Kvilinskyi, O. (2016). Impact of infrastructure component on socioeconomic approach to modernization of the region. European Cooperation, 8(15), 108-119.

Krahn, H. J., Lowe, G. S., Hughes, K. D. (2008). Work, Industry, and Canadian Society (6th ed.). Toronto, ON: Nelson Education.

Kwilinski, A., (2017). Development of industrial enterprise in the conditions of formation of information economics. Thai Science Review, Autumn 2017, 85 - 90. Retrieved from https://doi.org/10.5281/zenodo.1414236

Lakhno, V., Malyukov, V., Bochulia, T., Hipters, Z., Kwilinski, A., \& Tomashevska, O. (2018). Model of Managing of the Procedure of Mutual Financial Investing in Information Technologies and Smart City. International Journal of Civil Engineering and Technology, 98), 1802-1812. Retrieved from http://www.iaeme.com/MasterAdmin/UploadFolder/IJCIET_09_08_181//JCIET_09_ 08_181.pdf 
A. Kwilinski. Mechanism of Modernization of Industrial Sphere of Industrial Enterprise in Accordance with Requirements of the Information Economy

Lin, Justin, Chang, Ha-Joon (2009). Should Industrial Policy in Developing Countries Conform to Comparative Advantage or Defy it? A Debate Between Justin Lin and Ha-Joon Chang. Development Policy Review, 275), 483-502. Retrieved from https://doi.org/10.1111/j.1467-7679.2009.00456.x

Pajak, K., Kamińska, B., \& Kvilinskyi, O. (2016). Modern trends of financial sector development under the virtual regionalization conditions. Financial and credit activity: problems of theory and practice, 2(21), 204-217. Retrieved from https://doi.org/10.18371/fcaptp.v2i21.91052

Plohotnik, O. O. (2013). Information provision of management of production and financial potential of metallurgical enterprises in the conditions of the network economy. Collection of scientific works of the Tavriya State Agrotechnological University (economic sciences), 1(2), 232-238.

Reddy, G. S., Srinivasu, R., Rikkula, S. R., \& Rao, V. S. (2009). Management information system to help managers for providing decision making in an organization. International Journal of Reviews in Computing. Retrieved from http://www.jijic.org/volumes/Vol5/1Vol5.pdf

Yakubovskiy, M., Liashenko, V., Kamińska, B., \& Kvilinskyi, O. (2017). Economy modernization of industrial regions (based on the example of Ukraine). In P. Głowski \& O. Kvilinskyi (Eds.), Economic transformation in Ukraine: comparative analysis and European experience, (pp. 12-29). Warsaw: Consilium Sp. z o. o. Retrieved from https://institute-icd.org/wpcontent/uploads/2016/07/Monografia_Kvilinskyi.pdf

O. Квілінський, Ph.D., Лондонська академія науки і бізнесу (Великобританія).

Механізм модернізації виробничої сфери промислового підприємства згідно 3 вимогами інформаційної економіки

У статті встановлено, що для ефективного розвитку промислового підприємства в умовах інформаційної економіки слід модернізувати виробничу сферу підприємства. Головна мета дослідження - розробка оптимального механізму модернізації промислової сфери відповідно до вимог інформаційної економіки для розвитку промислового підприємства. Для вирішення цієї проблеми розроблено механізм модернізації виробничої сфери промислового підприємства відповідно до вимог інформаційної економіки, який базується на використанні моделі оцінки впливу заходів щодо модернізації виробничого сектора та моделі координації проектів модернізації промислової сфери. Це дає можливість автоматизації, роботизації та інформатизації виробничих та технологічних процесів промислового підприемства на основі збалансування критеріїв максимізації фінансових результатів та конкурентоспроможності. Встановлено, що розвиток промислового підприємства в умовах інформаційної економіки повинен базуватися на модернізації виробничого сектору, оскільки саме в цій галузі спостерігається найбільший розрив промислових підприємств з провідними підприємствами. Також аналіз досліджень у цьому напрямку дозволив зробити висновок, що проблема модернізації галузі не $\epsilon$ новою, але аспект розвитку промислового підприємства в процесі його адаптації до інформаційної економіки недостатньо освітлений. Тому існує необхідність розробки механізму модернізації виробничої сфери промислового підприємства відповідно до вимог інформаційної економіки, яка повинна містити інструменти для розвитку підприємства в контексті сучасної економіки та забезпечити формування проектів з модернізації виробничої сфеери, їх взаємної координації та узгодження планів реалізації, а також контролю за впровадженням. Пропонується побудувати механізм модернізації виробничої сфери промислового підприємства відповідно до вимог інформаційної економіки на основі використання моделі оцінки впливу заходів щодо модернізації виробничої сфери та модель координації проектів з модернізації виробничої сфери. Модель оцінки впливу заходів щодо модернізації виробничого сектору $\epsilon$ інструментом визначення впливу заходів щодо модернізації виробничого сектору на конкурентоспроможність промислового підприємства та його фінансових результатів, а також створення підстав для формування модернізації проектів, які є групами суміжних видів діяльності. Модель узгодження проектів модернізації промислового виробництва забезпечує вирішення таких завдань, як оцінка зв'язності та сумісності заходів модернізації, визначення ресурсних витрат заходів модернізації, визначення послідовності заходів модернізації, групування можливих заходів у проекти модернізації виробничого сектора. У подальших дослідженнях є необхідність розробки комплексу моделей та допоміжних інструментів, які є основою механізму модернізації виробничої сфери промислового підприємства, відповідно до вимог інформаційної економіки, що дозволяє обгрунтовувати та впроваджувати розробку промислової сфери промислового підприємства відповідно до особливостей функціонування в умовах інформаційної економіки.

Ключові слова: механізм, модернізація, виробнича сфера, промислове підприємство, інформаційна економіка, оцінка впливу, координація проекту.

Manuscript received: 27.10.2018

(C) The author(s) 2018. This article is published with open access at Sumy State University. 